NIHON REOROJĪ GAKKAISHI Vol. 23, No. 2, 95 101 (1995)

(C)1995 The Society of Rheology, Japan

\title{
Analysis of Rheology of Fiber Suspensions by the \\ Particle Simulation Method
}

\author{
Satoru Yамамото and Takaaki Matsuoka \\ Toyota Central Research \& Development Laboratories, Inc. \\ 41-1, Aza Yokomichi, Oaza Nagakute, Nagakute-cho, \\ Aichi-gun, Aichi 480-11, Japan
}

\begin{abstract}
A numerical simulation method has been developed to predict the rheological behavior of fiber suspensions in shear flow by using the particle simulation method (PSM), in which a fiber is modeled by arrays of spheres. The hydrodynamic interaction among fibers is considered by decomposing into intra- and inter- fiber ones. In the former, the many-body problem is solved by calculating the mobility matrix for each fiber to obtain the hydrodynamic force and torque exerted on each sphere. In the latter, only the near-field lubrication force is considered between spheres belonging to different fibers. The methodology was applied to predict the microstructure and the rheological properties of suspensions of rigid fibers with aspect rations 5 and 10 at several cancentrations. The overshoot of suspension viscosity due to the transient change from random to planar orientation in the microstructure was observed in semi-dilute to concentrated regimes.
\end{abstract}

Key Words : Fiber suspension/Particle simulation/Rheological property/Microstructure/Shear flow

\section{粒子シミュレーション法による繊維分散系のレオロジー解析}

\author{
山本 智* ・松岡孝明*
}

（原稿受理:1995年1月10日）

\section{1. 緒言}

繊維あるいは棒状粒子のサスペンジョンは複雑なレオロジー挙 動を示すことが知られている1) 4). レオペキシーやチキソトロ ピーがしばしば観察されることから, 分散粒子によって何らかの 構造が形成されているであろうことは想像できるが, 果たしてそ の構造が如何なるあのであるかを知ることは容易ではない，サス ペンジョンがかなり希薄でない限り, 内部の構造を直接観察する ことは团難であるからである ${ }^{5), 6)}$.

繊維強化樹脂の射出成形の分野においても, 成形中の流動状態 が成形品の品質に大きく影響するため, 溶融状態にある繊維強化 樹脂のレオロジー特性を知ることは重要である．樹脂に充填した 繊維が成形中に破断して所望の機械強度が得られなかったり, 緎 維配向によって機械的性質に異方性が生じてしまうことはよく経

\footnotetext{
*(侏豊田中央研究所 $\mathbf{7} 480-11$ 愛知県愛知郡長久手町大字長㴌字横道 41-1
}

験することである.

これら織維分散系のレオロジーには, 織維のアスペクト比, 緘 維長分布, 繊維の剛性, 分散状態, 繊維間および繊維と流体との 間の相互作用など多くの因子が複雑に関与している. 分散媒が ニュートン流体であってあサスペンジョンに弾性的性質が発現す ることああるため流動特性は複雑であり, レオロジー測定にも困 難を伴う場合が多い.

近年, 粒子分散系を対象とした計算機シミュレーションが行わ れるようになってきており, 構造粘性の現象解明7)や, 電気粘性 流体のレオロジー解析帛などに応用されている. 実験では容易に 知ることのできないサスペンジョン内部の構造を考察する上で, 計算機シミュレーションは有効な方法である. しかし, これらの 計算機シミュレーションは球形粒子を分散させたサスペンジョン を対象としたあのである. 最近, 繊維あるいは棒状粒子分散系の 計算機シミュレーションの一つの方法として, 粒子に回転楕円体 
を用いる方法を山根ら帛が提案した. ただし，この方法では剛体 として粒子を表すため，粒子の変形を扱うことはできない.

一般に, 瀻維サスペンジョンでは粒子の変形や破断が起こりや すく, 変形や破断に伴う㵶維長の変化によってレオロジー特性が 変化する. このことを考慮して, 筆者らは変形と破断を伴う繊維 の運動挙動を解析する方法として粒子シミュレーション法を提案

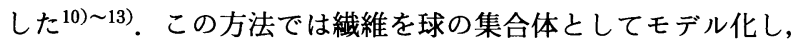
流動場において各球の運動方程式を解くことにより繊維全体の運 動を解析する．隣り合う球をバネで結合することによって緘維の 変形と破断を解析できることが特徵である.これまで, 流動場に おける 1 本の緘維の配向・変形・破断 $\left.\left.{ }^{10)}, 11\right), 13\right)$, 希薄系における 織維分散系の粘度 ${ }^{12)}$ について解析してきた. さらに, 繊維強化樹 脂の射出成形における織維配向問題へ適用する方法を提案し, ゲート近傍の拡大流れにおける繊維の運動解析を行った ${ }^{14)}$.

最近, 繊維内および瀻維間に流体力学的相互作用を考虑するこ とにより, 多数の㵶維が分散した濃厚系の解析を行う方法を提案 した ${ }^{15), 16)}$. 本研究では, 剛直な緎維が分散した系に本方法を適用 し, レオロジー解析を行った.

\section{2. 方法}

\section{$2 \cdot 1$ 紪維モデル}

粒子シミュレーション法では, アスペクト比 $N$ の緘維を半径 $a$ の球 $N$ 個を結合してFig. 1 に示すようにモデル化する. 隣り合 う球どうしは, 引張り・曲げ・ねじりの 3 種類のバネで結合され ており, Fig. 2 (a) 〜 (c) に示すように各変形が可能である. 㵶 維の引張り・曲げ・ねじりの各变形に対して, 変形量に比例した 復元力 $F^{s}$ あるいは復元トルク $T^{b}, T^{t}$ が式(1) (3)によって各球に 働く.このとき, 各変形に対する緘維の剛性を表す定数 $k_{s}, k_{b}$ お よび $k_{t}$ は繊維の縦弾性係数 (ヤング率) $E$ あるいは横弾性係数(剛 性率) $G$ を用いて表すことができる. ただし, $r$ は結合長, $\theta_{b}$ は結 合角, $\theta_{t}$ はねじり角の変位を各々表す.

$$
\begin{array}{ll}
F^{s}=-k_{s} r & \text { ただし, } k_{s}=\frac{\pi a}{2} E \\
T^{b}=-k_{b} \theta_{b} & \text { ただし, } k_{b}=\frac{\pi a^{3}}{8} E \\
T^{t}=-k_{t} \theta_{t} & \text { ただし, } k_{t}=\frac{\pi a^{3}}{4} G
\end{array}
$$

\section{$2 \cdot 2$ 支配方程式}

せん断流動場における㵶維サスペンジョンのレオロジー挙動を 計算する方法について述べる. 多数の瀻維が分散した系を表すた めにFig. 3 に示すように, 一辺の長さ $L$ の基本セル（体積 $V=$
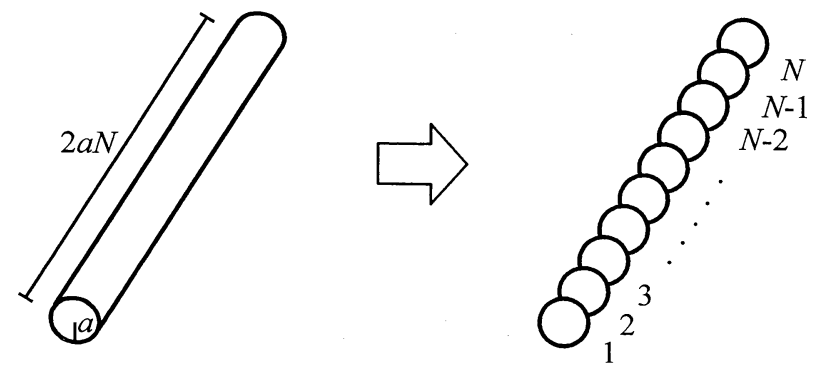

Fig. 1 Schematic illustration of a fiber constructed from $N$ spheres of radius $a$. (a)

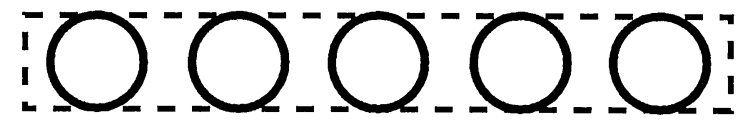

(b)

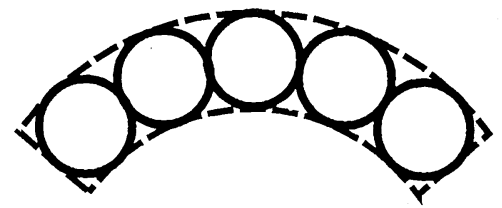

(c)

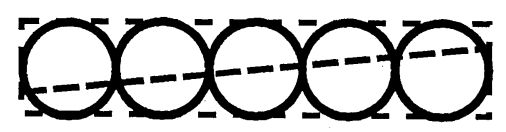

Fig. 2 Sketch of the fiber deformations for (a) stretching, (b) bending, and (c) twisting.

$\left.L^{3}\right)$ を考えて, 粘度 $\eta$ の分散媒中にアスペクト比 $N$ の瀻維 $N_{D}$ 本 をランダムに分散する. このとき, 体積分率は次式で定義される.

$$
\phi_{V}=\frac{4}{3} \pi a^{3} N N_{D} / L^{3}
$$

そこへ, せん断速度場を次式で与えて, 周期境界条件を考慮して 織維の運動を計算する.

$$
\nu_{x}=-\dot{r} y, \nu_{y}=0, \nu_{z}=0
$$

繊維を構成する各球の位置を $\mathbf{r}_{i}$, 配向角を $\boldsymbol{\theta}_{i}$, 速度を $\mathbf{V}_{i}$, 角速 度を $\omega_{i}$ で表すと, 各球の並進運動と回転運動の方程式および結 合した球との間で滑りが無い条件は式(6)〜(8)のようになる.

\section{Flow direction}

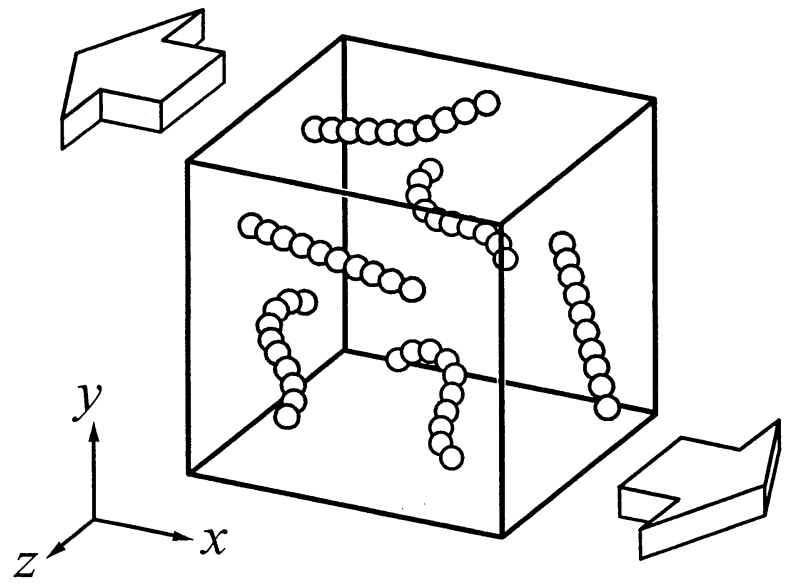

Fig. 3 Schematic illustration of fiber suspension in shear flow. Fibers constructed from $N$ spheres of radius $a$ are dispersed into a unit cell with periodic boundaries. 
$m \frac{d \mathbf{v}_{i}}{d t}=\Sigma \mathbf{F}_{i}^{s}+\Sigma \mathbf{f}_{i j}+\mathbf{F}_{i}^{h}+\Sigma \mathbf{F}_{i j}^{p}$

$\frac{2}{5} m a^{2} \frac{d \boldsymbol{\omega}_{i}}{d t}=\Sigma \mathbf{T}_{i}^{b}+\Sigma \mathbf{T}_{i}^{t}+\Sigma \mathbf{f}_{i j} \times a n_{i j}+\mathbf{T}_{i}^{h}$

$\mathbf{v}_{i}+a \boldsymbol{\omega}_{i} \times \mathbf{n}_{i j}=\mathbf{v}_{j}+a \boldsymbol{\omega}_{j} \times \mathbf{n}_{j i}$

ただし， $\mathbf{n}_{i j}$ は隣り合う球の中心を結ぶ方向の単位ベクトル

$$
\mathbf{n}_{i j}=\left(\mathbf{r}_{j}-\mathbf{r}_{i}\right) /\left|\mathbf{r}_{j}-\mathbf{r}_{i}\right|
$$

であり, $m$ は球の質量, $\mathbf{F}_{i}{ }^{h}$ 之 $\mathbf{T}_{i}{ }^{h}$ は各球が流体から受ける粘性力 と粘性トルクである. また, $\mathbf{F}_{i}{ }^{s}$ は引張り変形に対する復元力, $\mathbf{T}_{i}{ }^{b}$ は曲げ变形に対する復元トルク, $\mathbf{T}_{i}{ }^{t}$ はねじり変形に対する復元 トルク, $\mathbf{f}_{i j}$ は結合した球の間に働く摩擦力であり, 総和記号は両 側の球との間の力およびトルクを考えることを意味する． $\mathbf{F}_{i}{ }^{p}$ は 緘維間の流体力学的相互作用を表す項であり, 球 $i$ と他の緎維を 構成する球との間の力を考慮する. 式(6)～(8)を連立させて各球の 運動すなわち繊維全体の運動を計算する.

緘維分散流体の応力の各成分は, 球と流体との摩擦による散逸 エネルギーに基づいて求めることができ, 例えばせん断応力 $\sigma_{x y}$ と法線応力 $\sigma_{x x}$ は次のように表される.

$$
\begin{aligned}
\sigma_{x y} & =\left(1+\frac{5}{2} \phi\right) \eta\left(\kappa_{x y}+\kappa_{y x}\right)+\Delta \sigma_{x y} \\
\sigma_{x x} & =P+\Delta \sigma_{x x}
\end{aligned}
$$

ただし, $\boldsymbol{\kappa}$ は速度勾配テンソル, $P$ は圧力である. 式(10)の第 1 項は 粒子を分散したことによる寄与であり, 式(10)と(11)における第 2 項 が㵶維間の相互作用による寄与である．これらは次のように表す ことができる.

$$
\begin{aligned}
& \Delta \sigma_{x y}=\frac{1}{V}\left(\sum_{i} F_{i x}^{h} r_{i x}-\frac{1}{2} \sum_{i} T_{i z}^{h}\right) \\
& \Delta \sigma_{x x}=\frac{1}{V} \sum F_{i x}^{h} r_{i x}
\end{aligned}
$$

\section{$2 \cdot 3$ 流体力学的相互作用}

一般に, 粒子分散系の流体力学的相互作用は多体問題として扱 われるが, 本方法においてそれを用いることは計算量から考えて 現実的ではない，そこで, 流体力学的相互作用を繊維内と繊維間 に分けて扱うこととし, 織維間については潤滑近似を用いて近距 離の相互作用のみを考慮し, 遠距離のあのについては無視した.

はじめに織維内の流体力学的相互作用について述べる. 繊維を

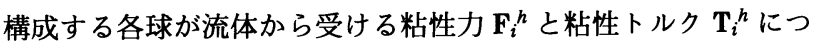
いては, 纎維内の流体力学的相互作用を考慮して, 次のように $N$ 個の球の間の多体問題として取り扱う. すなわち, 各球が流体か ら受ける力 $\mathbf{F}_{i}{ }^{h}$ とトルク $\mathbf{T}_{i}{ }^{h}$ は次のように表される.

$$
\left(\begin{array}{l}
\mathbf{F} \\
\mathbf{T}
\end{array}\right)=\mathbf{M}^{-1}\left(\begin{array}{c}
\mathbf{V}-\mathbf{V}_{0} \\
\Omega-\Omega_{0}
\end{array}\right)
$$

ここで, F, T は各球に㗢くカとトルクを表すべクトル $(3 N)$ であ り, $\mathbf{V}, \mathbf{V}_{0}, \Omega, \Omega_{0}$ は各球と流体の速度と角速度を表すべクトル (3N) である. また, M は流動性マトリックスと呼ばれる $6 N \times 6$ $N$ の行列である. 各時刻における纎維を構成する各球の配置から 行列 $\mathbf{M}$ を計算し, その逆行列を求めた後, 式(14)から各球に働く粘 性力と粘性トルクを計算する. この操作を全ての織維について行 う.

次に, 䌦維間の流体力学的相互作用については, ここでは潤滑 近似を用いて球と球との間の 2 体問題として取り扱うこととす

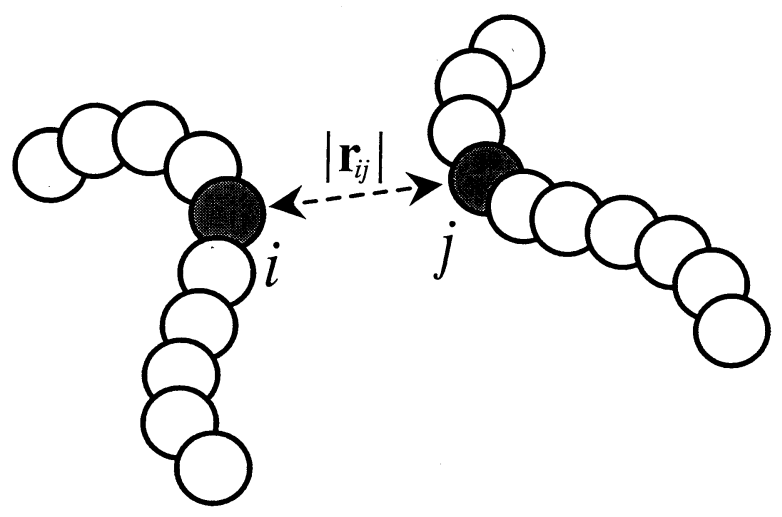

Fig. 4 Diagram of the interaction between fibers. The lubrication force exerts on spheres when the separation between spheres belonging to different fibermodels is close.

る. すなわち, Fig. 4 に示すように球 $i$ が他の瀻維を構成する球 $j$ に接近したときに, 次の力 $\mathbf{F}_{i j}^{p}$ が球 $i$ に㗢くあのとした.

$$
\begin{aligned}
& \mathbf{F}_{i j}^{p}=\frac{3}{2} a^{2} \pi \eta \frac{\left(\mathbf{v}_{j}-\mathbf{v}_{i}\right) \cdot \mathbf{n}_{i j}}{\left|\mathbf{r}_{j}-\mathbf{r}_{i}\right|-2 a} \mathbf{n}_{i j}, \text { ただし, } \\
& \left|\mathbf{r}_{j}-\mathbf{r}_{i}\right|<3 a \text { のとき }
\end{aligned}
$$

式(15)から分かるように，2つの球が接近するときには斥力が働き 離れようとするときには引力が働く．また， 2 球が接触すると力 は無限大になることから, この力を考慮するだけで球どうしの重 なり合いを防ぐことができることになる. しかし, 実際の計算で は誤差によってわずかな重なりが生じてしまう.そこで, 重なっ たときには剛体反発力を作用させて球どうしの重なりを防ぐこと とした.

\section{$2 \cdot 4$ 計算条件}

アスペクト比 5 および 10 の剛直な㵶維が分散した濃度 $0.1 〜$ $25 \mathrm{vol} \%$ のスペンジョンについて, 本方法を適用してせん断流 動場において織維が形成するミクロ構造とレオロジー挙動につい て計算を行った。

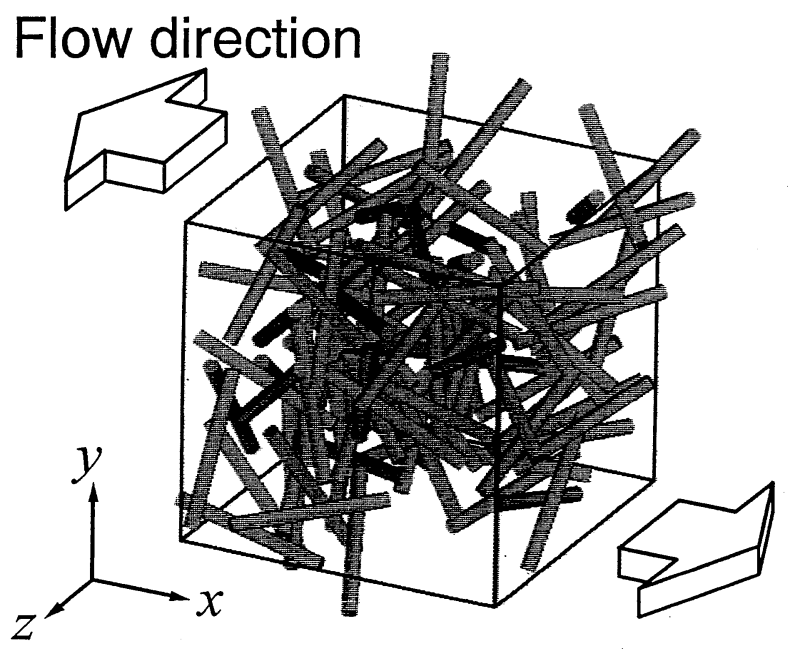

Fig. 5 Initial microstructure of 5 vol\% fiber suspension in shear flow. There are randomly-dispersed 100 fibers of aspect ratio 10 in the unit cell. 
繊維の剛性は, 流動場のせん断応力 $\eta \dot{\gamma}$ 之繊維のヤング率 $E$ と の比で定義することができる.ここでは, 織維が十分に剛直であ るように $\eta \dot{\gamma} / E=0.0002$ と設定した.

基本セル内に 100 本の繊維をランダムに分散した状態を初期条 件とした. 繊維の濃度は基本セルのサイズを变えることによって 調整した。例として，アスペクト比 10 の繊維が分散した $5 \mathrm{vol} \%$ の系について初期条件をFig. 5 に示す. 実際の計算では緎維は球 を結合したモデルを用いているが，円柱を用いて表示している. 時間, 長さ, 力をそれぞれ $1 / \dot{\gamma}, a, a^{2} \eta \dot{\gamma}$ で無次元化し, ストーク ス近似が成り立つように粒子のレイノルズ数 $R e\left(=a^{2} \rho \dot{\gamma} / \eta\right)$ を 0.1 として, 各条件でひずみ 1000 までの計算を行った.

\section{3. 結果と考察}

繊維の形成するミクロ構造の一例として, アスペクト比 10 の 繊維が分散した 5vol\%の場合をFig. 6 とFig. 7 に示す。 それぞ れ，ひずみ 10 のときのミクロ構造とひずみ 1000 のときのもので ある. 何れの場合にあ視点を変えた 2 つの図を示した. Fig. 6 の せん断流動場を与えた直後のミクロ構造では, 繊維が全体にせん 断方向 $(x$ 方向) に強く配向している.この状態から瀻維は $z$ 軸に 垂直な面内もしくはそれに近い軌道で回転運動をしょうとする が, 繊維どうしが互いに相互作用するため, 繊維どうしの衝突を 避けるように次第に $z$ 軸に近い軌道で運動するようになる。 その 結果, Fig. 7 に見られるように繊維は $y$ 軸に垂直な面内で運動す る構造へと変化する.
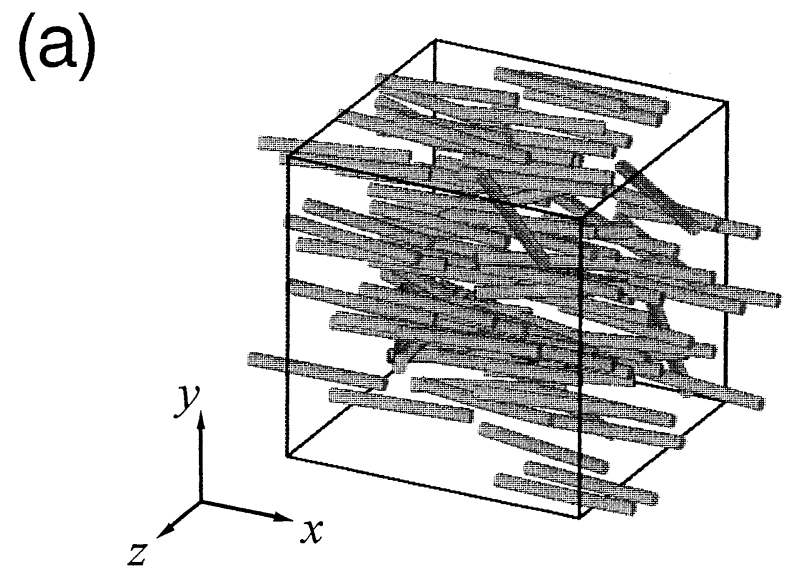

(b)

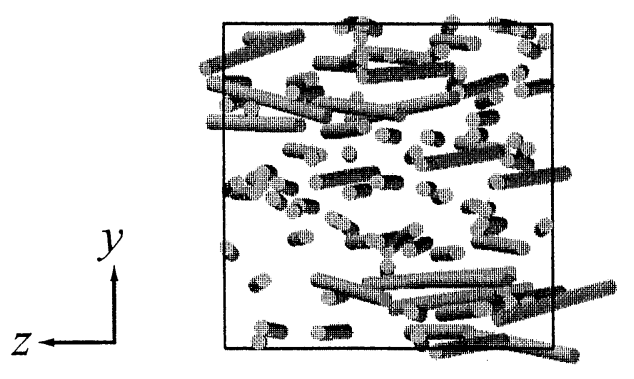

Fig. 6 Snapshots of the microstructure of the rigid fiber suspension at the early stage of a strain of 10 . Fibers strongly align in the shear direction. (a)

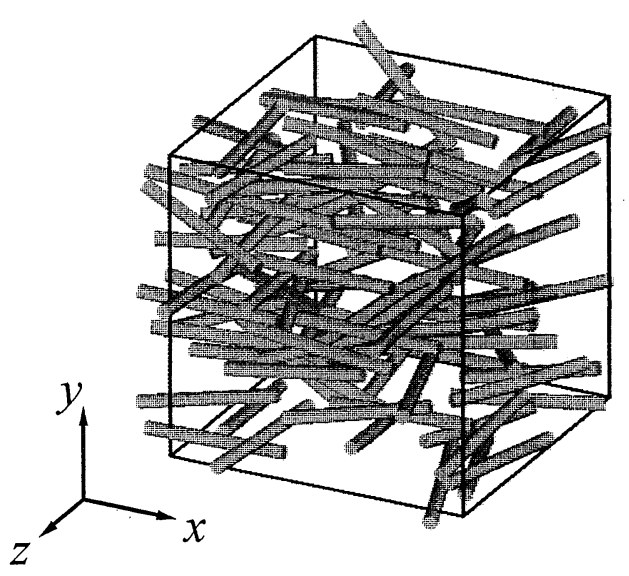

(b)

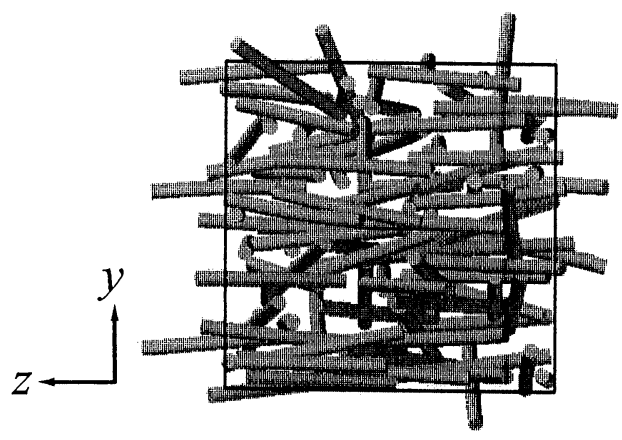

Fig. 7 Snapshots of the microstructure of the rigid fiber suspension at an equilibrium state of a strain of 1000. The planar orientation of fibers parallel to the $z-x$ plane is observed.

このようなミクロ構造の変化は, 織維の配向状態を調べると理 解することができる. 初期の状態で繊維の長軸方向と一致するよ うに各球に単位ベクトル $\mathbf{u}$ を固定しておき, その変化の様子を調 ベた. アスペクト比 10 の緘維が分散した系について, 濃度（a） 1vol\%，（b） $5 \mathrm{vol} \% ，(c ） 15 \mathrm{vol} \%$ の結果をFig. 8 に示した. 繊 維分散系は織維の濃度によって, 希薄系, 準希薄系 (準濃厚系), 濃厚系に分類される ${ }^{17)}$. アスペクト比 10 の繊維では約 $1 \sim 5 \mathrm{vol}$ \%が準希薄系である. したがって, (a)〜（c）はほぼこれらの分 類に対応する濃度である.

まず，ミクロ構造を先に示した（b）の $5 \mathrm{vol} \%$ の場合から見る と, せん断速度場を与えた直後には $x$ 成分が大きくなり, 繊維が $x$ 方向に強く配向することが分かる. 繊維間の相互作用によって 次第に $x$ 方向の成分が小さくなり, $z$ 方向の成分が大きくなる. このことから, 繊維は $y$ 軸に垂直な面内で運動していることにな り, 繊維が面内配向することが分かる. さらに注意して見ると, ひずみが約 60 までの初期の段階で大きな減衰振動が現れている. 振動は繊維の周期的な回転運動によるものである. せん断流度場 を与えた直後は初期条件の影響で全ての繊維が同じ位相で運動す るために振動がはっきりと現れる. しかし, 繊維間の相互作用に よって次第に各繊維が異なる運動をするようになるため振動が減 衰し, やがて消滅する。このような減衰振動は紻維が熱運動のよ うにランダムな運動をする場合に現れることが報告されてお $り^{18)}$, 今回の計算の場合には繊維間の流体力学的相互作用がその 


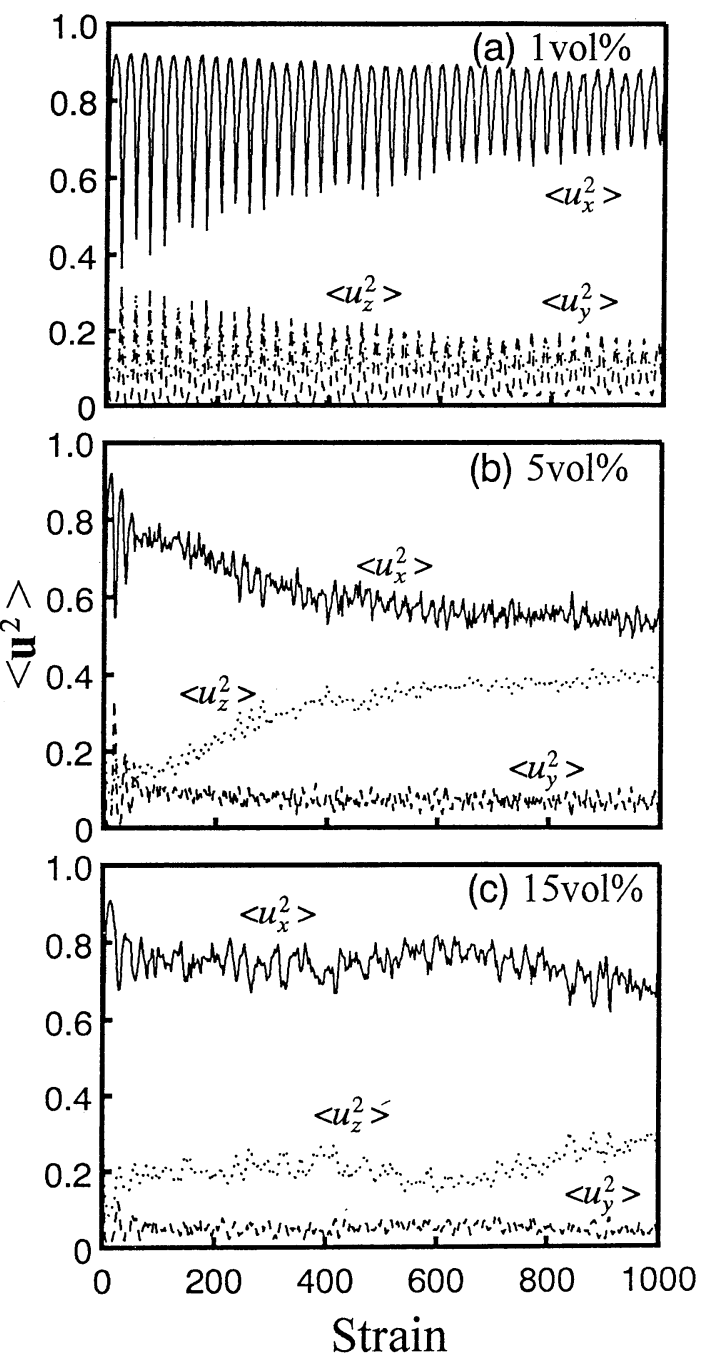

Fig. 8 Mean square unit vectors' as a function of strain for the rigid fiber suspensions of aspect ratio 10; (a) $1 \mathrm{vol} \%$, (b) $5 \mathrm{vol} \%$, and (c) $15 \mathrm{vol} \%$ Unit vectors are fixed at each sphere of fiber-models aligned to their major axis at the initial condition.

ようなランダムな運動を起こすあのと考えられる.

次に，(a)の 1vol\%の場合には繊維どうしがほとんど相互作用 しないために, 繊維の配向状態は変化していない，䋐維の回転運 動に基づく周期的な振動はわずかに減衰しているが, ひずみ 1000 においてあはっきり確認できる.この振動の周期が 25 であり, 織 維 1 本が単独で運動する場合の回転周期 ${ }^{11)}$ の $1 / 2$ にほぼ一致す ることからあ織維どうしの相互作用がほとんどないことが明らか である.

これとは対照的に（c）の場合には，(a) の場合と同じく緘維の 配向状態に大きな変化は見られないが, 周期的な振動は完全に消 滅している.これは濃厚系では繊維どうしの相互作用が非常に強 く, 各繊維が自由に運動できないためである.

アスペクト比 5 の織維が分散した系についても同様に, 各球に 固定した単位ベクトルの变化の様子をFig. 9 に示した. ただし, 繊維のアスペクト比が 5 の場合には約 2〜10 vol\%が準希薄系に
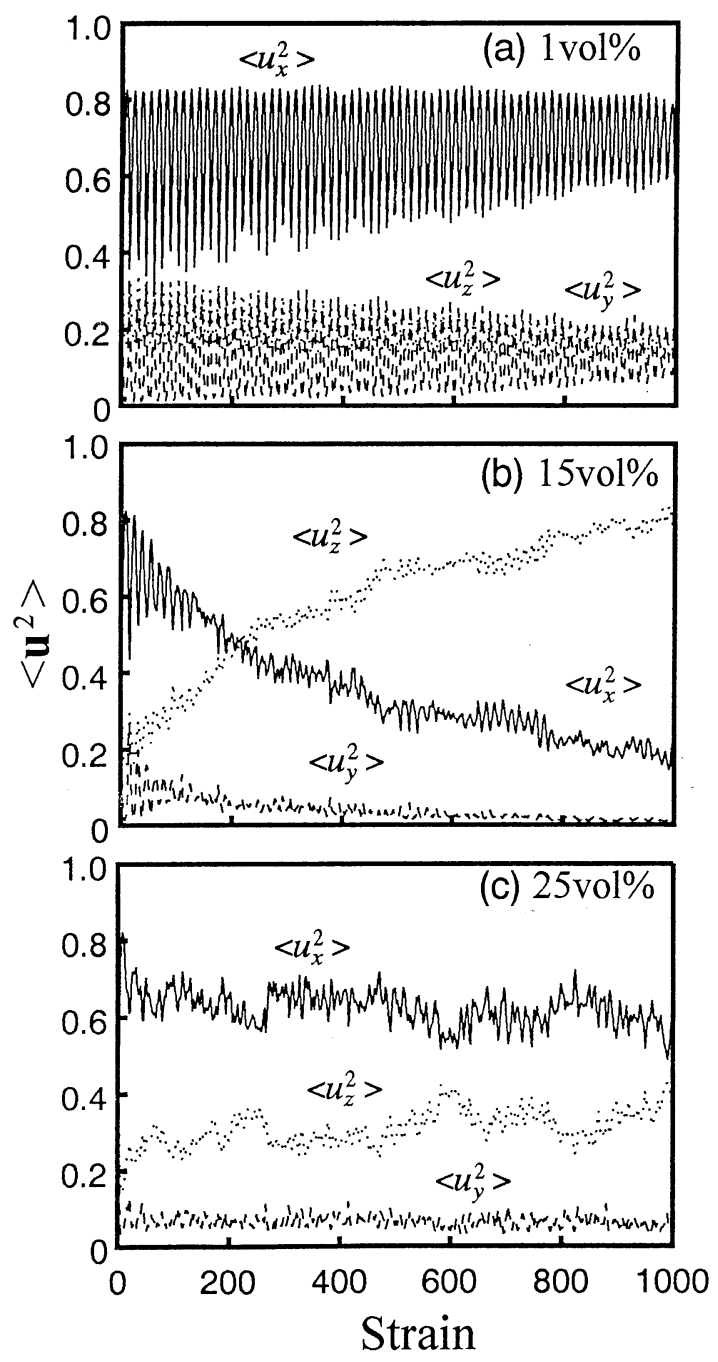

Fig. 9 Mean square unit vectors as a function of strain for the rigid fiber suspensions of aspect ratio 5 ; (a) 1 vol\%, (b) $15 \mathrm{vol} \%$, and (c) $25 \mathrm{vol} \%$.

分類される.アスペクト比 10 の場合と全く同じように，(a)の場 合には周期的な振動が続いている. その周期は約 12 と短いがこ れは織維のアスペクト比が小さいからである.（b）の場合にはミ ク口構造の変化が起こっており, やはり $y$ 軸に垂直な面内で繊維 が運動している. ただし，アスペクト比 10 の系に比べると $z$ 成分 が大きく, 緘維がより $z$ 軸方向に向いていることが分かる. 初期 の段階には，減衰振動が見られる，しかし，(c) のさらに濃厚な 場合には, 繊維が自由に運動できないために繊維配向の状態が変 化していない.

アスペクト比 10 の織維サスペンジョンについて, 粘度を計算 した結果をFig. 10 に示す. 粘度の振動が激しく, 長時間スケール での粘度变化の様子を読みとりにくいので, 平滑化した曲線も図 中に示してある．5vol\%と 10vol\%の場合には緩やかに粘度が減 少しており, 粘度のオーバーシュートが観察される.これは, 織 維の配向状態が変化したためである. すなわち, 緎維が $z$ 軸に垂 直な面内で運動するよりも $y$ 軸に垂直な面内で運動する方が流体 に対する抵抗が小さく, サスペンジョンの粘度を小さくするから 


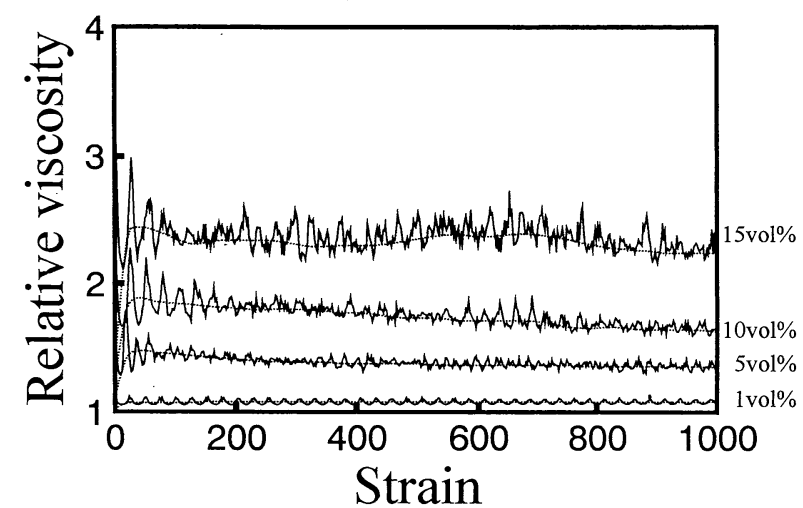

Fig. 10 Transient changes of relative viscosity for rigid fiber suspensions of aspect ratio 10. Smoothed data are indicated by dotted lines.

である ${ }^{12)}$ ．また，1vol\%の場合には繊維が周期的な回転運動をす るために, 粘度もそれと同じ周期で振動している. $15 \mathrm{vol} \%$ の濃厚 な場合には, 織維どうしの相互作用が強くミクロ構造が変化でき ないために粘度のオーバーシュートは見られない。

同様にアスペクト比 5 の系について粘度を計算した結果を Fig. 11 に示す. 10〜20vol\%の場合に粘度のオーバーシュートが 観察される. 以上の結果から考えると, 準希薄系から濃厚系にか けての濃度領域において, 緎維どうしが適度に相互作用する場合 にミクロ構造の変化とそれに伴う粘度のオーバーシュートが現れ るあのと考えられる.

今回行った緘維サスペンジョンについて, ミクロ構造が定常に 達した後の粘度をひずみ $900 \sim 1000$ の平均値として求めて, 濃度 に対してプロットするとFig. 12 のようになる. アスペクト比 5 および 10 の場合にも, ミク口構造の変化が顕著な準希薄系から 濃厚系にかけての濃度領域では平坦部が見られ, さらに濃厚にな ると粘度が急激に大きくなっていることが分かる.

今回計算した系に相当する実験データがないので厳密に比較す ることはできないが, 例えば Kitano ら ${ }^{4)}$ の実験ではガラス織維 （アスペクト比 $20 〜 30$ を充填したポリエチレン樹脂の相対粘度 が, 濃度 $8.4 \mathrm{vol} \%$ で 1.8, 13.5vol\%で 2.1, 19.6vol\%で 3.7 と, ア

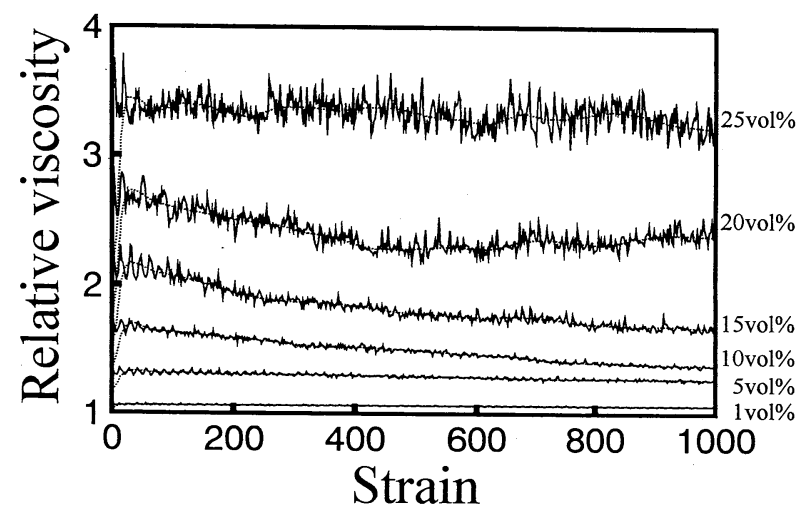

Fig. 11 Transient changes of relative viscosity for rigid fiber suspensions of aspect ratio 5. Smoothed data are indicatèd by dotted lines.

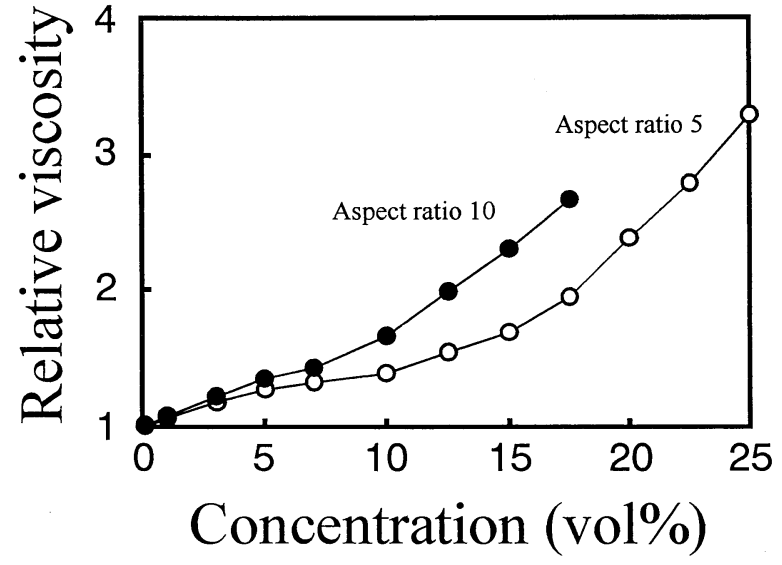

Fig. 12 Relation between relative viscosity and concentration for rigid fiber suspensions of aspect ratios 5 and 10. Data are average for last 100 strains.

スペクト比 10 の計算結果よりあ少し大きめではあるが同程度の 值であることから計算された粘度は妥当な大きさであると考え る.

なお，第一法線応力差についても計算を行ったが，今回計算し た濃度領域においては現れなかった，繊維が剛直である場合には 弾性的性質は発現しにくいあの之考える ${ }^{15)}$.

\section{4. まとめ}

球を結合したモデルで織維を表し，流動場において各球の運動 を計算するという粒子シミュレーション法を用いて繊維サスペン ジョンのレオロジー挙動を解析する方法を提案した．流体力学的 相互作用を繊維内と繊維間に分けて考虑することにより, 多数の 繊維が分散した流体の粒子シミュレーションが可能になった.

この方法をアスペクト比 5 および 10 の剛直な繊維が分散した サスペンジョンに適用し, ミクロ構造とレオロジー特性を調べ た. その結果，準希薄系から濃厚系にかけての濃度領域で繊維が 面内配向するようにミク口構造が変化し, それに伴って粘度の オーバーシュートが見られた。

\section{文献}

1) Mutel AT, Kamal MR, "Two-Phase Polymer Systems", Utracki LA ed (1991), Oxford University Press, NY, Chap 12, p321.

2）三上陽一，松本孝芳，小野木重治，日本レオロジー学会 誌，4, 86 (1976).

3) Kitano T, Kataoka T, Rheol Acta, 20, 390 (1981).

4) Kitano T, Kataoka T, Nagatsuka Y, Rheol Acta, 23, 20 (1984).

5) Anczurowski E, Cox RG, Mason SG, J Colloid Interface Sci, 23, 533 (1967).

6) Stover CA, Kock DL, Cohen C, J Fluid Mech, 238, 277 (1992).

7) Doi M, Chen D, J Chem Phys, 90, 5271 (1989).

8）山本智, 松岡孝明, 高橋秀郎, 倉内紀雄, 日本レオロジー 学会誌, 20, 56 (1992). 
9) Yamane Y, Kaneda Y, Doi M, J Non-newtonian Fluid Mech, 54, 405 (1994).

10）山本智, 松岡孝明, 日本レオロジー学会第 19 年会講演予 稿集, 35 (1992).

11) Yamamoto S, Matsuoka T, J Chem Phys, 98, 644 (1993).

12) Yamamoto S, Matsuoka T, J Chem Phys, 100, 3317 (1994).

13) Yamamoto S, Matsuoka T, Polym Eng Sci, (in press).
14）松岡孝明, 山本智, 日本レオロジー学会誌（投稿中).

15）山本智, 松岡孝明, 日本レオロジー学会第 21 年会講演予 稿集, 53 (1994).

16）山本智, 松岡孝明, 第 43 回高分子討論会予稿集, 3405 (1994).

17) Doi M, Edward SF, "The Theory of Polymer Dynamics” (1989), Oxford University Press, NY, Chap 9, p324.

18) Zuzovsky M, Priel Z, Mason SG, J Colloid Interface Sci, 75, 230 (1980). 